\title{
ANALYSIS OF THE HEIGHT DIFFERENCE OF THE ZERO ISOTHERM ACCORDING TO TWO TEMPERATURE PROFILERS
}

\author{
E.A. BOLELOV ${ }^{1}$, O.V. VASILIEV ${ }^{2}$, K.I. GALAEVA ${ }^{1}$, S.A. ZIABKIN ${ }^{1}$ \\ ${ }^{1}$ Moscow State Technical University of Civil Aviation, Moscow, Russia \\ ${ }^{2}$ JSC “International Aeronavigation Systems Concern”, Moscow, Russia
}

\begin{abstract}
One of the main indicators characterizing the quality of meteorological support of flights is the justifiability of aviation weather forecasts and forecasts of dangerous weather phenomena. For the detection and prediction of dangerous meteorological weather phenomena are currently used very advanced systems, which include meteorological radar stations near the airfield zone. The reliability of the forecast of such dangerous weather events as icing, thunderstorms, hail, squally wind according to the information from the meteorological radar stations of the near airfield zone significantly depends on the data on the height of the zero isotherm. The correctness of the entered values of the zero isotherm position directly affects the probability of false alarms, and, consequently, the degree of justification of weather forecasts and forecasts of dangerous weather events. The source of information about the position of the zero isotherm can serve as radiosonding data of the atmosphere. However, the data of aerological radiosonding of the atmosphere are not operational. In addition, at present, obsolete systems are used on Roshydromet aerological network in addition to fairly modern aerological radar systems. This, in conjunction with the sufficiently low cost of the network of aerological stations on the territory of the Russian Federation does not allow the operational use of radiosonding data to determine the height of the zero isotherm at a particular airport. An alternative source of information about the position of the zero isotherm for solving the problems of meteorological location are temperature profilers. Temperature Profiler refers to the remote means of measuring the parameters of the atmosphere, and the principle of its operation is based on the methods of radiometry. Use the temperature of a caliper can be operatively obtain information about the temperature profile at the airport and, therefore, it can be a source for weather radar data on the zero isotherme, and isotherme $-22^{\circ} \mathrm{C}$, which is also used to identify hazardous weather phenomena. In this paper, the spatial variability of the zero isotherm position is analyzed according to the data of two temperature profilers. As a result of experimental studies, it was determined that within a radius of about 10 kilometers from the installation site of the Profiler, the measured temperature profiles remain virtually unchanged. This result can be used in the development of methods of placement of meteorological support for flights at the airport. Of practical interest are similar studies for airfields located in the mountainous, coastal and other geographical regions of Russia.
\end{abstract}

Key words: temperature profiler, temperature profile, flight safety, meteorological support of flights, freezing level, weather hazard.

\section{INTRODUCTION}

According to the Federal Aviation Regulations ${ }^{1}$, meteorogical service is provided for the purpose of safety, regularity and response security of civil aviation flights. In view of this meteorogical bulletins, weather forecasts, weather hazard (WH) forecasts, and other meteorogical data are developed and provided to the relevant users, such as crews, air traffic management office, airfield service, etc., by airfield meteorogical office (AMSC, AMC, etc). Forecast development for such WH as thunderstorms, storm rainfalls, icing, squall winds, hail precipitation, severe turbulence and wind shear largely relies on meteorogical observation and measurement data. These measures are conducted at the airfield [1-3].

Notably sophisticated meteorogical systems, such as short-distance airfield meteo radars (SDAMR) are used with the aim of WH sighting and forecast. Veracity of meteorogical observations, conducted by using SDAMR, and forecasts, provided on the ground of these searches, substantially depends on freezing level data. For instance, freezing level is used with the aim of thunderstorm, hail precipitation, squall winds, whirlwind identification and hydrometeor phase state recognition while radar observation. Input freezing level data authenticity broadly influences the

\footnotetext{
${ }^{1}$ FAR "Preparation and Implementation of Civil Aviation Flights of the Russian Federation". No 128. July, 31. 2009.
} 
probability of SDAMR false alarms, and, consequently, meteorogical forecast and WH forecast success rate degree.

Radiosonde observation data in the form of relative and irrelative baric topography maps might serve as a reference source in terms of freezing level. Besides that, temperature distribution data, which was received after every certain radiosonde output, may be used at the airfield, providing that aerologic radiosonde observation station is located over a distance of not more than 10 kilometers from the airfield fix point.

Along with that, it's necessary to notice that aerologic radiosonde observation data isn't investigative because radiosonde observation is conducted only twice a day, at 00:00 UTC and 12:00 UTC. Besides that, nowadays there are about 30 ARS (aerological radar systems ) AVK, which have already run its course, along with sufficiently updated MARLA-(T), VEKTOR - M, RAM-1 (2) at the upperair network of The Russian Federal Service for Hydrometeorology and Environmental Monitoring. The nominative operational endurance of the greater part of ARS AVK is overdrawn greater than twice, in which connection technical specification of AVK frequently turns out not to match the updated standards of radiosonde systems.

Sufficiently serious challenge for the radiosonde network of the Russian Federal Service for Hydrometeorology and Environmental Monitoring is a deficiency of highly qualified aerologists, which can't help but affect the quality of the meteorogical data reduction. The conducted analysis of radiosonde observation data showed that the procedure and technical errors of the aerologists are not uncommon.

All the above in conjunction with sufficiently low full value of aerogical stations network on the territory of the Russian Federation doesn't allow to use the radiosonde observation data with the aim of freezing level recognition at the certain airfield ${ }^{2}$.

Temperature BGT, for instance, MTR-5, may serve as an alternative reference source in terms of a freezing level for the purpose of the solution to the problems of meteolocation. The microwave temperature BGT MTR-5 is the most admissible means of temperature distribution measurement, in contradistinction to SODAR and RASS [4-6] systems. It provides the measurement of temperature at the surface upward to 1000 meters with the discretization in 5 minutes [7-10]. Blending technique is used to derivate temperature distribution higher than $1000 \mathrm{~m}$. This is the integration of temperature distribution observations Temperature BGT MTR-5 is the investigative means of obtaining data on temperature distribution at the airfield and may serve as an extra data source in terms of freezing level for SDAMR or in terms of the freezing level $-22^{\circ} \mathrm{C}$, which is also used with the aim of WH identification.

Alongside this, pinpoint location of BGT requires answering the question: on what distance is its information representative for using it in radar data reduction algorithms? Answering this question allows us to form recommendations for recognition of an appropriate temperature BGT MTR-5 installation area at the airfield.

The present article covers the questions of freezing level spatial variability and height difference analysis, according to the data of the two BGT MTR-5.

\section{FREEZING LEVEL ESTIMATED AND EXPERIMENTAL DATA INFLUENCE ON WEATHER HAZARD IDENTIFICATION}

The updated SDAMR works in the mode SEGMENT alongside with the major mode SURVEY. The mode SEGMENT permits WH sighting in the segments of the aircraft taking-off and landing. Trial runs of SDAMR "Monocle", conducted in "Group of Companies "International Air Nav-

\footnotetext{
${ }^{2}$ Radiosonde plan. Federal State Budgetary Institution "Central Aerologic Observatory". Available at: http://caontcr.mipt.ru/monitor/stuff/upperair/upperair-rf2017 (accessed 25.10.2019).
} 
igation Systems" showed the high WH forecast success rate degree of the present weather radar. Along with WH sighting (among others, wind shear and turbulence), this SDAMR precipitates the phase of hygrometeorogical evolutions (snowfall, rainfall, ice rain, supercooled droplets, etc). Hydrometeor phase precipitating can be implemented in two ways:

- on the ground of dual polarization data (differential reflectivity, cross-correlation, differential phase shift);

- on the ground of vertically-integrated liquid water content data and temperature distribution at the weather radar installation point.

In terms of the second way $\mathrm{WH}$ forecast success rate degree, according to the data of SDAMR, largely depends on freezing level recognition accuracy $\left(0^{\circ} \mathrm{C}\right.$ and $\left.-22^{\circ} \mathrm{C}\right)$. Freezing level data is either accounted in SDAMR according to the data of the weather base at the airfield (temperature at the surface at the altitude of 2 meters and gradient of the temperature at the surface within the conditions of normal air $-6,5^{\circ} \mathrm{C} / \mathrm{km}$ ), or actual freezing level experimental value is set into the weather radar. Meanwhile, experimental freezing level data is with highest priority because it provides more qualitative solving of WH identification problems.

There is the weather events map according to the data of the SDAMR "Monocle" at Pulkovo airfield (17.07.2015) in Figure 1. Freezing level estimated data $(2900 \mathrm{~m})$ was used in the aim of the map development.

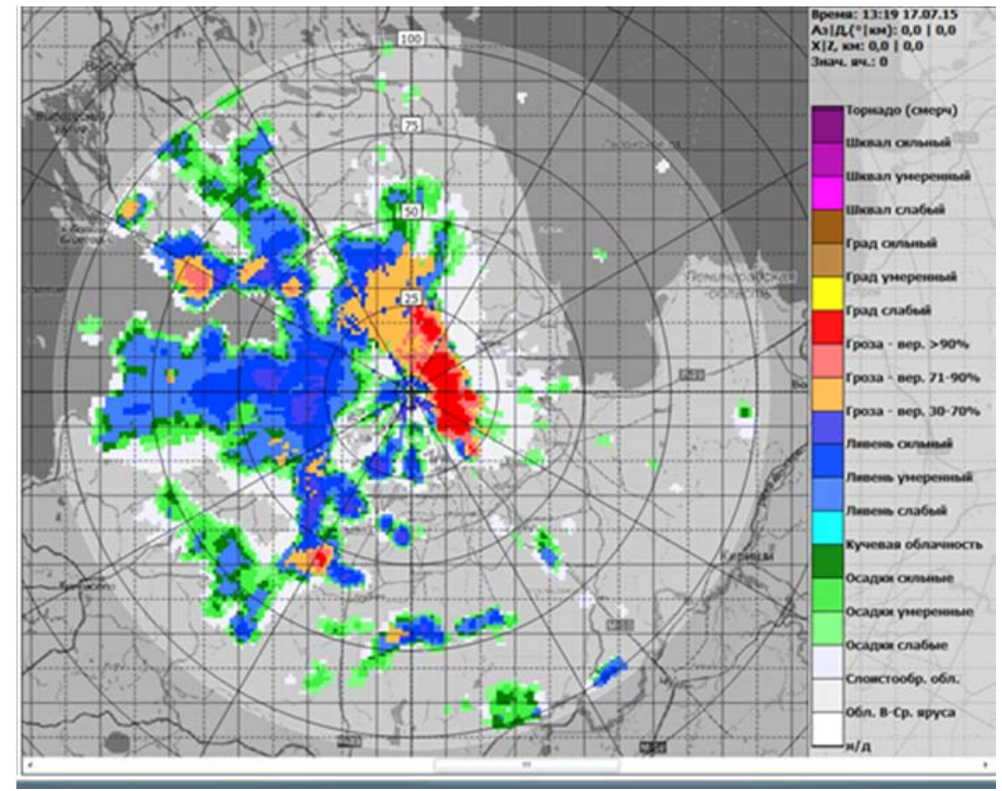

Fig.1. Map of meteorological phenomena according to MRLS BZ «Monocle» at the calculated freezing level

Some zones (marked with black) were missed in the SDAMR "Monocle" while using freezing level estimated data. Hail precipitation was being factually observed in these zones. Hail precipitation was identified according to DML-S of The Russian Federal Service for Hydrometeorology and Environmental Monitoring meteoradar network data (Figure 2).

There is the weather events map according to the data of the SDAMR "Monocle" in Figure 3. Freezing level experimental data $(2395 \mathrm{~m})$ was used in the aim of the map development according to the temperature distribution data of upper-air sounding station ("Voeykovo" AS). The areas of hail precipitation storm centers according to the data of SDAMR "Monocle" coincided in space and time with the ones according to the data of DML - S while using freezing level experimental data. 


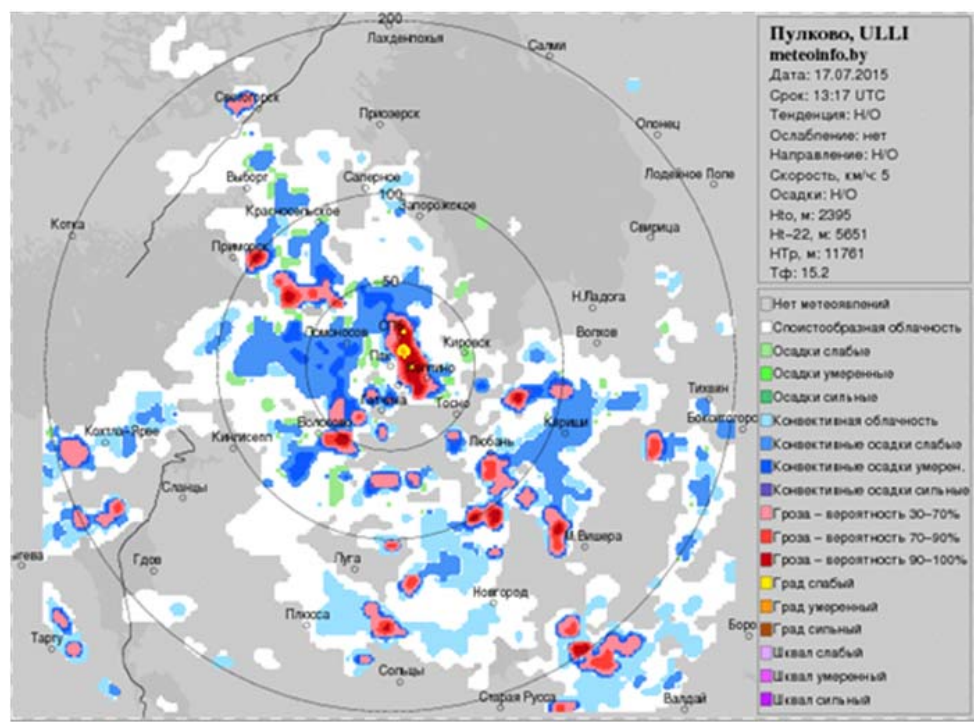

Fig. 2. Map of meteorological phenomena according to DMRL-C

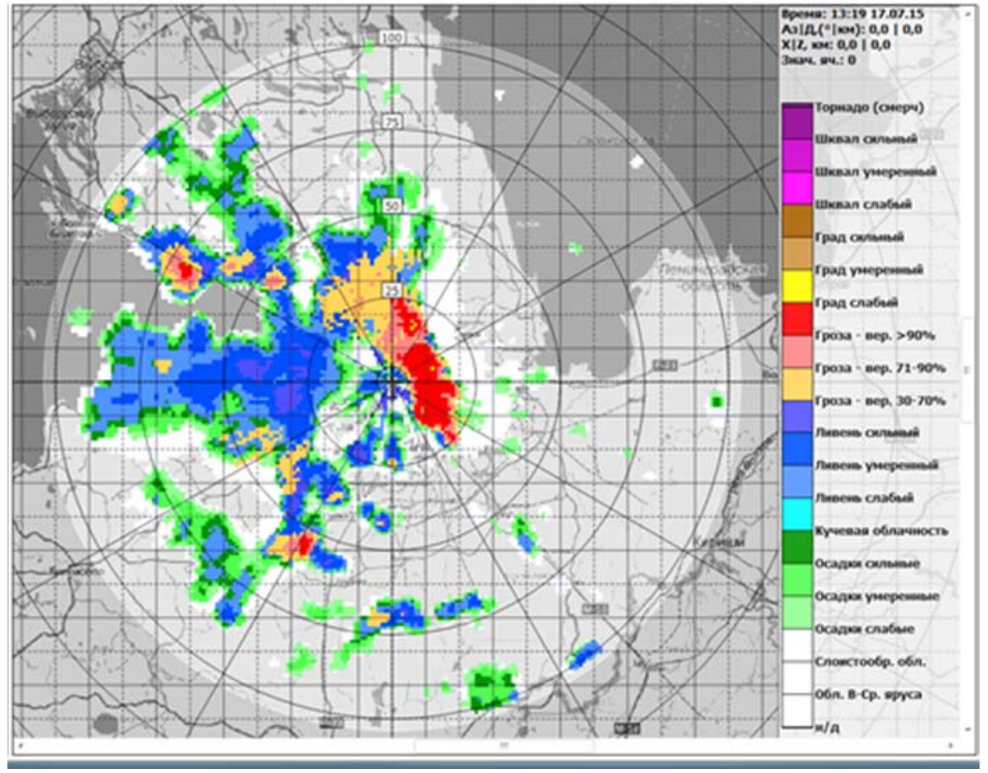

Fig. 3. Map of meteorological phenomena according to MRLS BZ «Monocle» at the actual freezing level

Thus, freezing level experimental data permit to avoid mistakes while identifying WH and to increase weather forecast success rate degree. This is utterly important for flight security at the airfield.

\section{EXPERIMENTAL ESTIMATE OF FREEZING LEVEL SPATIAL VARIABILITY AT THE AIRFIELD}

Experimental research was conducted in order to analyze the freezing level height difference and estimate the freezing level spatial variability according to the data of the two MTR-5. The BGT were spaced-apart. The two single -type temperature BGT were installed at "Orlovka" airfield and in the country of Abutkovo, Tver Region. 


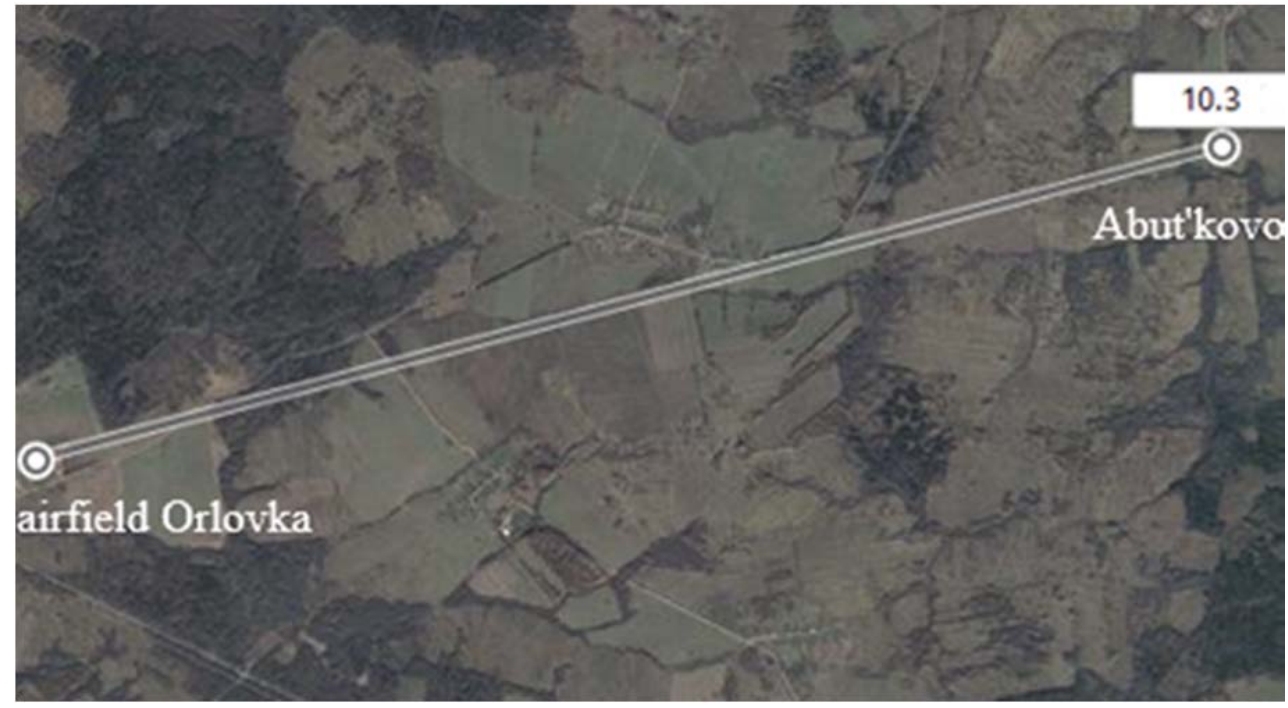

Fig. 4. Placement of temperature profilers MTR-5

The research was conducted in winter time $(18.01 .2019-18.02 .2019)$. There is temperature BGT MTR-5 installation, demonstrated in Figure 4. BGT were spaced-apart at a distance of about 10 kilometers long.

While conducting the experimental research and handling its data, they didn't take the following cases into consideration:

- when the freezing level was registered near the ground (up to dozens of degrees)

- there was frontal passage, because frontal zones are distinct in remarkable changes in the temperature at the surface (up to dozens of degrees).

With this in mind, handling the experiment data was being conducted for a sampling size of 161 measurements. Handling of the two temperature BGT data resulted in the following:

- the maximum value of the freezing level height differences is $600 \mathrm{~m}$;

- the minimum value of the freezing level height differences is $-200 \mathrm{~m}$;

- the mid-value of the freezing level height differences is $27,64 \mathrm{~m}$;

- the standard deviation of the freezing level height differences is $169,64 \mathrm{~m}$.

There is a histogram of the freezing level height differences proportioning, according to the data of the two MTR-5 in Figure 5.

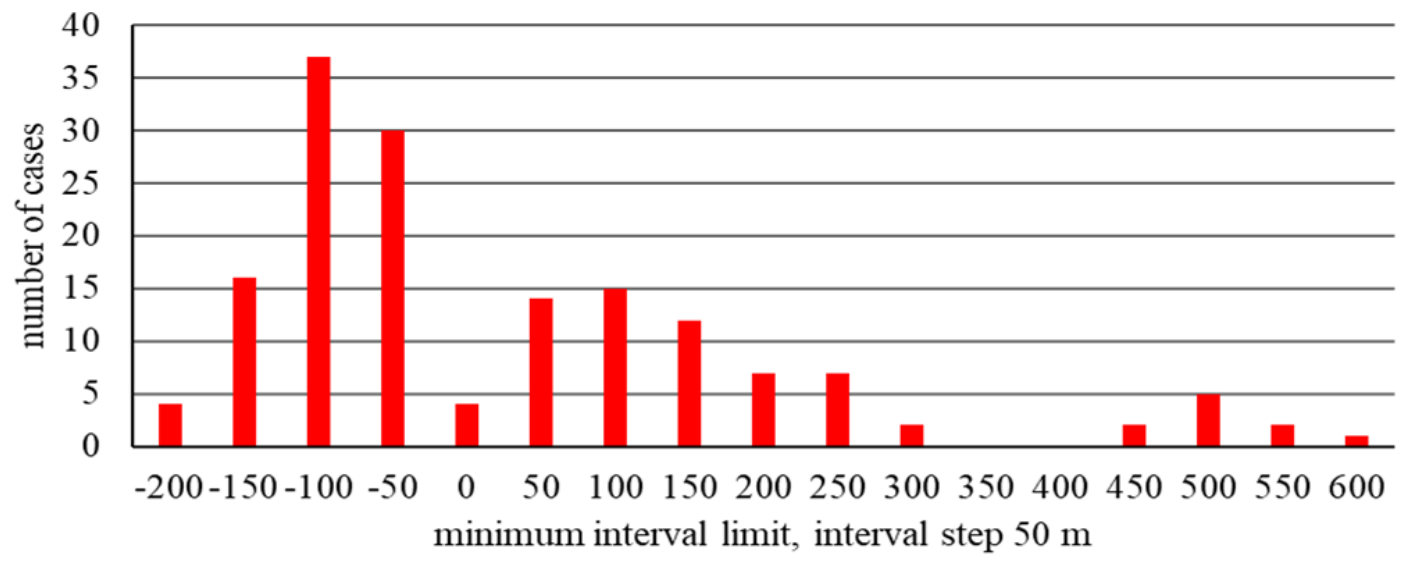

Fig. 5. Histogram of the distribution of the height difference of the freezing level according to two MTR-5 
It should be noted that it's important to take into account the changes in the freezing levels at two points during the advective heat transfer while setting the freezing level data into SDAMR. Such cases were not detected in the present sample.

Thus, the experimental data shows us that the freezing level height difference varies within a relatively narrow range - from $-200 \mathrm{~m}$ to $600 \mathrm{~m}$. The roughness of the freezing level height differences deviation (more than $200 \mathrm{~m}$ in absolute value) is $12 \%$. These results permit to make an important conclusion. There is a practical possibility of using the one temperature BGT MTR-5 data within a raduis of $10 \mathrm{~km}$ from its installation point with the aim of setting the derivated values of the freezing level height into SDAMR. Derivated data (from one MTR-5) may be used for estimating the hydrometeor phase in meteoradar at the airfield in the segments of the aircraft taking-off and landing, including the detection of possible icing areas.

\section{CONCLUSION}

The conducted experimental research showed us that using the two temperature BGT permits to prolong obtained temperature distribution values in the radius of $10 \mathrm{~km}$ from the installation area and to apply obtained temperature distribution values of one of them while carrying take-off and landing manoeuvres out. Along with that, experimental research was conducted in the winter period and for the certain district in Tver Region. Further experimental researches in different seasons and in different regions of the Russian Federation are of some practical interest. Besides that, the methods of detecting the spatial and temporal changes in the temperature distribution according to the results of some temperature BGT MTR-5 measurements is also of some practical interest [12-13]. More accurate freezing level data might be derivated by a complex handling of temperature BGT (such as BGT) data and the results of temperature distribution measurement during the certain radiosonde output at the airfield. Using the Unmanned Aerial Vehicle as the means of the radiosonde getting up is the most appropriate way in these purposes [14].

\section{REFERENCES}

1. Bogatkin, O.G. (2009). Osnovy aviatsionnoy meteorologii [Fundamentals of Aviation Meteorology]. St.Petersburg: Ed. RGGMU, 339 p. (in Russian)

2. Bogatkin, O.G. (2010). Aviatsionnyye prognozy pogody: uchebnoye posobie [Aviation Weather Forecasts]. 2nd ed., ster., St.Petersburg: BHV-Petersburg, 288 p. (in Russian)

3. Seleznev, V.P. (2018). Meteorologicheskoe obespechenie poletov [Meteorological Support of Flights]. Moscow: Knizhnyy dom «LIBROKOM», 190 p. (in Russian)

4. Emeis, S., Munkel, C., Vogt, S., Muller, W.J. and Schafer, K. (2004). Atmospheric boundary-layer structure from simultaneous SODAR, RASS and ceilometer measurement. Atmospheric Environment, vol. 38, no. 2, pp. 273-286.

5. Keder, J. (1999). Detection of inversions and mixing height by REMTECH PA2 Sodar in comparison with collocated radiosonde measurement. Meteorology and Atmospheric Physics, vol. 71, iss. 1/2, pp. 133-138. DOI: 10.1007/s007030050051

6. Walezewski, J. and Feleksi-Bielak, M. (1988). Diurnal variation of characteristic sodar and the diurnal change of atmospheric stability. Atmospheric Environment, vol. 22, no. 2, pp. 1793-1800.

7. Kadygrov, E.N. (2009). Microwave radiometry of atmospheric boundary layer: method, equipment, and applications. Optika atmosfery i okeana, vol. 22, no. 7, pp. 697-704. (in Russian)

8. Kadygrov, E.N., Kuznetsova, I.N., Ganshin, E.V., Gorelik, A.G., Knyazev, A.K., Miller, E.A., Nekrasov, V.V., Tochilkina, T.A. and Shaposhnikov, A.N. (2017). Modern experience of using ground-based microwave radiometric systems for the study of atmospheric parameters. Optika atmosfery i okeana, vol. 30, no. 6, pp. 502-508. DOI: 10.15372/AOO20170609. (in Russian) 
9. Kadygrov, E.N., Ganshin, E.V., Miller, E.A. and Tochilkina, T.A. (2015). Groundbased microwave temperature profilers: potential and experimental data. Atmospheric and ocean optics, vol. 28, no. 6, pp. 521-528. DOI: 10.1134/S102485601506007X

10. Kuznetsova, I.N., Kadygrov, E.N., Miller, E.A. and Nahaev, M.I. (2012). Characteristics of lowest $600 \mathrm{~m}$ atmospheric layer temperature on the basis of MTP-5 profiler data. Optika atmosfery i okeana, vol. 25, no. 10, pp. 877-883. (in Russian)

11. Galaeva, K.I., Bolelov, E.A., Khuberman, B.I., Yeshchenko, A.A. and Daletskiy, S.V. (2018). Justification of tasks, solved by near-airfield meteorological radar complex. Scientific Bulletin of The State Scientific Research Institute of Civil Aviation, no. 20 (331), pp. 74-81. (in Russian)

12. Reshetov, V.D. (1973). Izmenchivost meteorologicheskikh elementov $v$ atmosfere [Variability of Meteorological Elements in the Atmosphere]. Leningrad: Gidrometeoizdat, 215 p. (in Russian)

13. Borisenko, M.M. (1974). Vertikalnye profili vetra i temperatury $v$ nizhnikh sloyakh atmosfery [Vertical Profiles of Wind and Temperature in the Lower Atmosphere]. Trudy GGO [Proceedings of the Main Geophysical Observatory], iss. 320, 205 p. (in Russian)

14. Bolelov, E.A., Korablev, Y.N., Baranov, N.A., Demin, S.S. and Yeshchenko, A.A. (2018). Integrated processing of meteorological data in a mobile airfield complexes of meteorical and sounding of the atmosphere. Scientific Bulletin of The State Scientific Research Institute of Civil Aviation, vol. 20 (331), pp. 82-92. (in Russian)

\title{
INFORMATION ABOUT THE AUTHORS
}

Eduard A. Bolelov, Candidate of Technical Sciences, Associate Professor, Head of Technical Maintenance of Aircraft Radio-electronic Equipment Chair, Moscow State Technical University of Civil Aviation, e.bolelov@mstuca.aero.

Oleg V. Vasiliev, Doctor of Technical Sciences, Professor, Chief Designer - Head of Direction JSC “International Aeronavigation Systems Concern” (IANS), vas_ov@mail.ru.

Ksenia I. Galaeva, Postgraduate Student of Technical Maintenance of Aircraft Radio-electronic Equipment Chair, Moscow State Technical University of Civil Aviation, ks.galaeva@mail.ru.

Sergey A. Ziabkin, Postgraduate Student of Technical Maintenance of Aircraft Radio-electronic Equipment Chair, Moscow State Technical University of Civil Aviation, s.zyabkin@ians.aero.

\section{АНАЛИЗ РАЗНОСТИ ВЫСОТ НУЛЕВОЙ ИЗОТЕРМЫ ПО ДАННЫМ ДВУХ ТЕМПЕРАТУРНЫХ ПРОФИЛЕМЕРОВ}

\author{
Э.А. Болелов ${ }^{1}$, О.В. Васильев ${ }^{2}$, К.И. Галаева ${ }^{1}$, С.А. Зябкин ${ }^{1}$ \\ ${ }^{1}$ Московский государственный технический университет гражданской авиации, \\ 2. Москва, Россия \\ ${ }^{2}$ АО «Концерн «Международные аэронавигационные системы»», г. Москва, Россия
}

Одним из основных показателей, характеризующих качество метеорологического обеспечения полетов, является оправдываемость авиационных метеопрогнозов и прогнозов опасных метеорологических явлений погоды. Для обнаружения и прогноза опасных метеорологических явлений погоды в настоящее время используются весьма совершенные системы, к которым относятся метеорологические радиолокационные стации ближней аэродромной зоны. Достоверность прогноза таких опасных метеоявлений, как обледенение, грозы, град, шквалистый ветер по информации от метеорологических радиолокационных станций ближней аэродромной зоны в существенной степени зависит от данных о высоте нулевой изотермы. Корректность введенных значений положения нулевой изотермы напрямую влияет на вероятность ложных тревог, а следовательно, и на степень оправдываемости метеопрогнозов и прогнозов опасных метеоявлений. Источником информации о положении нулевой изотермы могут служить данные радиозондирования 
атмосферы. Однако данные аэрологического радиозондирования атмосферы не являются оперативными. Кроме этого, в настоящее время на аэрологической сети Росгидромета помимо достаточно современных аэрологических радиолокационных систем используют морально устаревшие системы. Сказанное, в совокупности с достаточно низкой полностью сети аэрологических станций на территории Российской Федерации, не позволяет оперативно использовать данные радиозондирования для определения высоты нулевой изотермы на конкретном аэродроме. Альтернативным источником информации о положении нулевой изотермы для решения задач метеолокации являются температурные профилемеры. Температурный профилемер относится к дистанционным средствам измерения параметров атмосферы, а принцип его работы основан на методах радиометрии. С помощью температурного профилемера можно оперативно получать информации о профиле температуры на аэродроме и, следовательно, он может выступать источником необходимых для метеорологической радиолокационной станции данных о нулевой изотерме, а также о изотерме $-22^{\circ} \mathrm{C}$, которая тоже используется для идентификации опасных метеоявлений. В настоящей статье проведен анализ пространственной изменчивости положения нулевой изотермы по данным двух температурных профилемеров. В результате экспериментальных исследований определено, что в радиусе около 10 километров от места установки профилемера измеренные профили температуры остаются практически неизменными. Этот результат может быть использован при разработке методик размещения средств метеорологического обеспечения полетов на аэродроме. Практический интерес также представляют аналогичные исследования для аэродромов, расположенных в горных, приморских и других географических регионах России.

Ключевые слова: температурный профилемер, профиль температуры, безопасность полетов, метеорологическое обеспечение полетов, нулевая изотерма, опасные метеоявления.

\section{СПИСОК ЛИТЕРАТУРЫ}

1. Богаткин О.Г. Основы авиационной метеорологии. СПб.: Изд.РГГМУ, 2009. 339 с.

2. Богаткин О.Г. Авиационные прогнозы погоды: учеб. пособие. 2-е изд. стер. СПб.: БХВ-Петербург, 2010. 288 с.

3. Селезнев В.П. Метеорологическое обеспечение полетов. М.: Книжный дом «ЛИБРОКОМ», 2018. $190 \mathrm{c}$.

4. Emeis S. Atmospheric boundary-layer structure from simultaneous SODAR, RASS and ceilometer measurement / S. Emeis, C. Munkel, S. Vogt, W.J. Muller, K. Schafer // Atmospheric Environment. 2004. Vol. 38, no. 2. Pp. 273-286.

5. Keder J. Detection of inversions and mixing height by REMTECH PA2 Sodar in comparison with collocated radiosonde measurement // Meteorology and Atmospheric Physics. 1999. Vol. 71, iss. 1/2. Pp. 133-138. DOI: 10.1007/s007030050051

6. Walezewski J. Diurnal variation of characteristic sodar and the diurnal change of atmospheric stability / J. Walezewski, M. Feleksi-Bielak // Atmospheric Environment. 1988. Vol. 22, no 2. Рp. 1793-1800.

7. Кадыгров Е.Н. Микроволновая радиометрия атмосферного пограничного слоя: метод, аппаратура, результаты измерений // Оптика атмосферы и океана. 2009. Т. 22, № 7. С. 697-704.

8. Кадыгров Е.Н. Современный опыт использования данных наземных микроволновых радиометрических систем для измерения параметров атмосферы / Е.Н. Кадыгров, И.Н. Кузнецова, Е.В. Ганьшин, А.Г. Горелик, А.К. Князев, Е.А. Миллер, В.В. Некрасов, Т.А. Точилкина, А.Н. Шапошников // Оптика атмосферы и океана. 2017. Т. 30, № 6. С. 502-508. DOI: $10.15372 / \mathrm{AOO} 20170609$

9. Кадыгров Е.Н. Наземные микроволновые температурные профилемеры: потенциал и реальность / Е.Н. Кадыгров, Е.В. Ганьшин, Е.А. Миллер, Т.А. Точилкина // Оптика атмосферы и океана. 2015. Т. 28, № 6. С. 521-528. DOI: 10.15372/AOO20150604

10. Кузнецова И.Н. Характеристики температуры в нижнем 600-метровом слое по данным дистанционных измерений приборами МТП-5 / И.Н. Кузнецова, Е.Н. Кадыгров, Е.А. Миллер, М.И. Нахаев // Оптика атмосферы и океана. 2012. Т. 25, № 10. С. 877-883. 
11. Галаева К.И. Обоснование задач, решаемых метеорологическим радиолокационным комплексом ближней аэродромной зоны / К.И. Галаева, Э.А. Болелов, И.Б. Губерман, А.А. Ещенко, С.В. Далецкий // Научный вестник ГосНИИ ГА. 2018. № 20 (331). С. 74-81.

12. Решетов В.Д. Изменчивость метеорологических элементов в атмосфере. Л.: Гидрометеоиздат, 1973. 215 с.

13. Борисенко М.М. Вертикальные профили ветра и температуры в нижних слоях атмосферы // Труды ГГО. 1974. Вып. 320. 205 с.

14. Болелов Э.А. Комплексная обработка метеоинформации в аэродромных мобильных комплексах метеолокации и зондирования атмосферы / Ю.Н. Кораблев, Н.А. Баранов, С.С. Демин, А.А. Ещенко // Научный вестник ГосНИИ ГА. 2018. № 20. С. 82-92.

\section{СВЕДЕНИЯ ОБ АВТОРАХ}

Болелов Эдуард Анатольевич, кандидат технических наук, доцент, заведующий кафедрой технической эксплуатации радиоэлектронного оборудования воздушного транспорта МГТУ ГА, e.bolelov@mstuca.aero.

Васильев Олег Валерьевич, доктор технических наук, профессор, главный конструктор - руководитель направления АО «Концерн «Международные аэронавигационные системы», vas_ov@mail.ru.

Галаева Ксения Игоревна, аспирантка кафедры технической эксплуатации радиоэлектронного оборудования воздушного транспорта МГТУ ГА, ks.galaeva@mail.ru.

Зябкин Сергей Алексеевич, аспирант кафедры технической эксплуатации радиоэлектронного оборудования воздушного транспорта МГТУ ГА, s.zyabkin@ians.aero.

$\begin{array}{llll}\text { Поступила в редакцию } & 05.11 .2019 & \text { Received } & 05.11 .2019 \\ \text { Принята в печать } & 23.01 .2020 & \text { Accepted for publication } & 23.01 .2020\end{array}$

